\title{
Axial Concentration Profiles and NO Flue Gas in a Pilot-Scale Bubbling Fluidized Bed Coal Combustor
}

\author{
Luís A. C. Tarelho,* Manuel A. A. Matos, and Fernando J. M. A. Pereira \\ Environment and Planning Department, University of Aveiro, 3810-193 Aveiro, Portugal
}

Received March 8, 2004. Revised Manuscript Received July 1, 2004

\begin{abstract}
Atmospheric bubbling fluidized bed coal combustion of a bituminous coal and anthracite with particle diameters in the range 500-4000 $\mu \mathrm{m}$ was investigated in a pilot-plant facility. The experiments were conducted at steady-state conditions using three excess air levels $(10,25$, and $50 \%$ ) and bed temperatures in the $750-900{ }^{\circ} \mathrm{C}$ range. Combustion air was staged, with primary air accounting for 100,80 , and $60 \%$ of total combustion air. For both types of coal, high NO concentrations were found inside the bed. In general, the NO concentration decreased monotonically along the freeboard and toward the exit flue; however, during combustion with high air staging and low to moderate excess air, a significant additional NO formation occurred near the secondary air injection point. The results show that the bed temperature increase does not affect the NO flue gas concentration significantly. There is a positive correlation between excess air and the NO flue gas concentration. The air staging operation is very effective in lowering the NO flue gas, but there is a limit for the first stage stoichiometry below which the NO flue gas starts rising again. This effect could be related with the coal rank.
\end{abstract}

\section{Introduction}

Due to its lower operational temperature, relative to more conventional combustion systems, atmospheric fluidized bed coal combustion (AFBCC) has comparatively lower $\mathrm{NO}_{x}$ emissions, because they result mostly from fuel-N oxidation. The NO is an important atmospheric pollutant, since it contributes to global effects such as acidification, eutrophization, and photochemical smog. It is also an intermediate in the formation of $\mathrm{N}_{2} \mathrm{O}$ in combustion systems, which is an important contributor to the global warming effect and stratospheric ozone depletion.

There is almost a general consensus in the literature supporting that there is a direct correlation between the NO emission and the bed temperature. ${ }^{1-12}$ However,

* Corresponding author. Tel: +351 234370 200. Fax: +351 234 429 290. E-mail: ltarelho@dao.ua.pt.

(1) Pereira, F. J. M. A. Ph.D. Thesis, University of Sheffield, Sheffield, 1975 .

(2) Young, B. C.; Mann, M. D.; Collings, M. E. In Processing and Utilization of High-Sulfur Coals V; Parekh, B. K., Groppo, J. G., Eds.; Elsevier: New York, 1993; p 419 .

(3) Takeshita, M. Environmental performance of coal-fired FBC; IEA Coal Research, 1994.

(4) Pels, J. R.; Wójtowicz, M. A.; Kapteijn, F.; Moulijn, J. A. Energy Fuels 1995, 9 (5), 743.

(5) Anthony, E. J.; Preto, F. In Pressurized Fluidized Bed Combustion; Cuenca, M.A., Anthony, E. J., Eds.; Blackie Academic and Professional, London, 1995; Chapter 3, p 80.

(6) Bramer, E. A. In Coal Science and Technology 22, Atmospheric Fluidized Bed Coal Combustion, Research, Development and Application; Valk, M., Ed.; Elsevier: Amsterdam, The Netherlands, 1995; Chapter 2, p 51.

(7) Gulyurtlu, I. Fuel 1995, 74 (2), 253.

(8) Hannes, J. Ph.D. Thesis, Delft University of Technology, The Netherlands, 1996.

(9) Leckner, B. Prog. Energy Combust. Sci. 1998, 24, 31.

(10) Lan, J.; Zhong, Z.; Jin, B.; Huang, Y.; Li, D. 16th International Conference on FBC; ASME, 2001; p 162.

(11) Miccio, F.; Loffler, G.; Wargadalam, V.; Winter, F. Fuel 2001, 80,1555 . some experimental results show also that a maximum, ${ }^{7,13}$ or even a decrease, ${ }^{13}$ can occur in the range of bed temperatures from 750 to $900{ }^{\circ} \mathrm{C}$. A direct correlation between the NO emission and excess air has been systematically reported before. ${ }^{1,2,5-9,11-18}$ Decreasing the first stage stoichiometry by air staging has been also a successful strategy in minimizing the NO emission. ${ }^{1,2,6,10,12,14,19-21}$ However, there is a maximum limit for the effectiveness of NO abatement by air staging, $6,18,22-24$ and it would appear that first stage stoichiometries in the range of $0.9-1$ should give the best results. ${ }^{3,25}$

In this paper, we report the results of $\mathrm{NO}$ axial concentration profiles and flue gas measurements ob-

(12) Zevenhoven, R.; Kilpinen, P. Nitrogen. In Control of Pollutants in Flue Gases and Fuel Gases; ISBN 951-22-5527-8; Helsinki University of Technology Course ENE-47.153, 2002; Chapter 4

(13) Shimizu, T.; Tachiyama, Y.; Souma, M.; Inagaki, M. 11th International Conference on FBC; ASME, 1991; p 695.

(14) Bramer, E. A.; Valk, M. 11th International Conference on FBC; ASME, 1991; p 701.

(15) Brown, R. A.; Muzio, L. 11th International Conference on FBC; ASME, 1991; p 719 .

(16) Amand, L.-E. Ph.D. Thesis, Chalmers University of Technology, Sweden, 1994

(17) Goel, S. K.; Beér, J. M.; Sarofim, A. F. 13th International Conference on FBC; ASME, 1995; p 887.

(18) Jensen, A. Ph.D. Thesis, Department of Chemical Engineering, Technical University of Denmark, Lyngby, Denmark, 1996.

(19) Valk, M.; Bramer, E. A.; Toissant, H. H. J. 9th International Conference on FBC; ASME, 1987; p 784.

(20) Wang, X. S.; Gibbs, B. M.; Rhodes, M. J. Combust. Flame 1994, 99,508 .

(21) Shimizu, T.; Miura, M.; Togashi, T.; Tonsho, M.; Inagaki, M.; Matsukata, M. 13th International Conference on FBC; ASME, 1995; p 1083.

(22) Lyngfelt, A.; Leckner, B. Fuel 1993, 72 (11), 1553.

(23) Jensen, A.; Johnsson, J. E.; Andries, J.; Laughlin, K.; Read,

G.; Mayer, M.; Baumann, H.; Bonn, B. Fuel 1995, 74 (11), 1555.

(24) Jensen, A.; Johnsson, J. E. Chem. Eng. Sci. 1997, 52 (11), 1715

(25) Tatebayashi, J.; Okada, Y.; Yano, K.; Ikeda, S. 6th International Conference on FBC; ASME, 1980; p 986. 
tained in a pilot-scale atmospheric bubbling fluidized bed coal combustor (ABFBCC) and offer some qualitative interpretation relevant to the chemistry of $\mathrm{NO}$ formation and destruction during coal combustion.

\section{NO Chemistry in Combustion}

During AFBCC the NO results essentially from the oxidation of fuel-N during the burning stages of char and volatile matter, through competitive and complex formation and destruction mechanisms involving both homogeneous and heterogeneous (catalytic and noncatalytic) reactions. ${ }^{26-28}$ Their relative rates are sensitive to temperature and oxygen availability. The char$\mathrm{N}, \mathrm{HCN}$, and $\mathrm{NH}_{3}$ are the most important precursors of NO, but they also act as true "predators" as soon as the latter is formed. The catalytic effect of some free radicals (such as $\mathrm{H}, \mathrm{O}$, and $\mathrm{OH}$ ) and some surfaces (such as sand, calcinated limestone, char, and coal ash) also play an important role in these reactions. As a result, the actual NO concentrations found in a combustion system are the net result of a balance between its rates of formation and destruction. The basic reaction routes in the rather complex chemistry of NO in AFBCC seem to have been identified. However, a clear picture of the phenomena involved is hindered by the complex nature of both the hydrodynamics and the gas-solid contact pattern in the bed and in the freeboard.

Gas-phase homogeneous reactions of NO formation are often associated with the burning of volatile matter, where $\mathrm{NH}_{3}$ and $\mathrm{HCN}$ have been identified as the main precursors. . $^{3,4,6,12,16,18,26}$ These two species appear to be the dominant gaseous nitrogen species evolved during coal devolatilization. ${ }^{29,30}$ In fact, whereas $\mathrm{HCN}$ can result from heterocyclic pyrrole and pyridinic groups in the coal volatiles, ${ }^{4,31} \mathrm{NH}_{3}$ arises mostly from amine groups. ${ }^{32,33}$ In this respect, the $\mathrm{NH}_{3}$ origin has been questioned, since, as a general rule, the coal functional groups containing nitrogen decompose with $\mathrm{HCN}$ formation. ${ }^{31}$ Several researchers have identified HCN as the main product arising during coal devolatilization. $4,31,34,35$ However, it is possible that during the process, the $\mathrm{NH}_{3}$ can result from the $\mathrm{HCN}$ hydrogenation $^{31,32,36-38}$ or direct hydrogenation of coal/char-N. ${ }^{39}$

Both $\mathrm{NH}_{3}$ and $\mathrm{HCN}$ could be the origin of $\mathrm{NO}$; while at the temperatures typical of AFBCC the $\mathrm{NH}_{3}$ seems

(26) Johnsson, J. E. Fuel 1994, 73 (9), 1398

(27) Thomas, K. M. Fuel 1997, 76 (6), 457.

(28) Glarborg, P.; Jensen, A. D.; Johnsson, J. E. Prog. Energy Combust. Sci. 2003, 29, 89.

(29) Nelson, P. F.; Li, C.-Z.; Ledesma, E. Energy Fuels 1996, 10 (1) 264

(30) Zhang, H.; Fletcher, T. H. Energy Fuels 2001, 15, 1512

(31) Li, C.-Z.; Nelson, P. F.; Ledesma, E. B.; Mackie, J. C. 26th Symposium (International) on Combustion; The Combustion Institute, 1996 ; p 3205.

(32) Furimsky, E.; Ohtsuka, Y. Energy Fuels 1997, 11 (5), 1073.

(33) Kelemen, S. R.; Gorbaty, M. L.; Kwiatek, P. J.; Fletcher, T. H.

Watt, M.; Solum, M. S.; Pugmire, R. J. Energy Fuels 1998, 12 (1), 159.

(34) Wójtowicz, M. A.; Pels, J. R.; Moulijn, J. A. Fuel Process.

Technol. 1993, 34, 1 .

(35) Boavida, D. H. Ph.D. Thesis, Faculdade de Ciências e Tecnologia, Universidade Nova de Lisboa, Portugal, 1997.

(36) Wójtowicz, M. A.; Zhao, Y.; Serio, M. A.; Bassilakis, R.; Solomon, P. R.; Nelson, P. F. In Coal Science and Technology 24, 8th Int. Conf on Coal Science; Pajares, J. A., Tascón, J. M. D., Eds.; Elsevier: Amsterdam, The Netherlands, 1995; p 771.

(37) Kilpinen, P.; Kallio, S.; Hupa, M. 15th International Conference on FBC; ASME, 1999; p 155.

(38) Schafer, S.; Bonn, B. Fuel 2000, 79, 1239

(39) Chang, L.; Xie, Z.; Xie, K.-C.; Pratt, K. C.; Hayashi, J.-I.; Chiba,

T.; Li, C.-Z. Fuel 2003, 82, 1159. to yield mostly NO, $18,26,37,40-48$ the NO originated from $\mathrm{HCN}$ is temperature dependent and has been discussed in the context of a $\mathrm{NO} / \mathrm{N}_{2} \mathrm{O}$ tradeoff, the $\mathrm{NO}$ formation prevailing at the higher temperatures. ${ }^{4,18,34,49-54}$ The intermediate species that are crucial in the $\mathrm{NH}_{3}$ and $\mathrm{HCN}$ oxidation appear to be $\mathrm{NH}$ for the first and $\mathrm{NCO}$ for the second.

Two main mechanisms account for homogeneous reactions of NO destruction in the gas phase: (i) reduction by $\mathrm{NH}_{3}$ and $\mathrm{NCO}^{18,26,41-43,45,48,55,56}$ and (ii) reduction by combustible gaseous species $\left(\mathrm{H}_{2}, \mathrm{CO}\right.$, and hydrocarbon radicals). ${ }^{44,57}$ The rates of these reactions are strongly increased at high temperatures.

Reactions that are responsible for the heterogeneous (noncatalytic) formation of NO can occur directly as the result of a char- $\mathrm{N}$ surface reaction ${ }^{27,58-60}$ or indirectly as a result of the release of nitrogen intermediates ( $\mathrm{HCN}, \mathrm{NH}_{3}, \mathrm{NCO}$ ), which then react homogeneously in the gas phase via the mechanisms mentioned above. ${ }^{31,53,61-63}$

Reactions responsible for the heterogeneous (noncatalytic) destruction of $\mathrm{NO}$ can occur at selective active sites on the char surface. ${ }^{4,26,58-60,64-79}$ The presence of species

(40) Miller, J. A.; Bowman, C. T. Prog. Energy Combust. Sci. 1989 15,287

(41) Duo, W.; Dam-Johansen, K.; Ostergaard, K. Can. J. Chem. Eng. 1992, 70 (10), 1014

(42) Ostberg, M.; Dam-Johansen, K. Chem. Eng. Sci. 1994, 49 (12), 1897.

(43) Glarborg, P.; Dam-Johansen, K.; Miller, J. A. Int. J. Chem. Kinet. 1995, 27, 1207.

(44) Glarborg, P.; Alzueta, M. U.; Dam-Johansen, K.; Miller, J. A. Combust. Flame 1998, 115, 1.

(45) Zijlma, G. J.; Gerritsen, A. W.; van den Bleek, C. M. 15th International Conference on FBC; ASME, 1999; p 168.

(46) Kilpinen, P.; Norstrom, T.; Mueller, C.; Kallio, S.; Hupa, M. 38th IEA Fluidized Bed Conversion Meeting, 1999, p 25.

(47) Loffler, G.; Andahazy, D.; Wartha, C.; Winter, F.; Hofbauer H. 16th International Conference on FBC; ASME, 2001; p 68.

(48) Loffler, G.; Wartha, C.; Winter, F.; Hofbauer, H. Energy Fuels 2002, 16, 1024.

(49) Kilpinen, P.; Hupa, M. Combust. Flame 1991, 85, 94.

(50) Hulgaard, T.; Dam-Johansen, K. AIChE J. 1993, 39 (8), 1342

(51) Glarborg, P.; Miller, J. A. Combust. Flame 1994, 99, 475.

(52) Kramlich, J. C.; Linak, W. P. Prog. Energy Combust. Sci. 1994 20,149

(53) Winter, F.; Wartha, C.; Loffler, G.; Hofbauer, H. 26th Symposium (International) on Combustion; The Combustion Institute, 1996; p 3325 .

(54) Hayhurst, A. N.; Lawrence, A. D. Combust. Flame 1996, 105, 341

(55) Wenli, D.; Dam-Johansen, K.; Ostergaard, K. 23th Symposium (International) on Combustion; The Combustion Institute, 1990; 297. (56) Glarborg, P.; Dam-Johansen, K.; Miller, J. A.; Kee, R. J.; Coltrin, M. E. Int. J. Chem. Kinet. 1994, 26, 421.

(57) Wargadalam, V. J.; Loffler, G.; Winter, F.; Hofbauer, H. Combust. Flame 2000, 120, 465

(58) De Soete, G. G. Rapport No. 35861, Techniques d'Applications Energetiques, Institut Français du Pétrole, 1988.

(59) De Soete, G. G. Rapport No. 36752, Techniques d'Applications Energetiques, Institut Français du Pétrole, 1989.

(60) De Soete, G. G. 23th Symposium (International) on Combustion;

The Combustion Institute, 1990; 1257.

(61) Jones, J. M.; Harding, A. W.; Brown, S. D.; Thomas, K. M. Carbon 1995, 33 (6), 833.

(62) Wang, W. X.; Thomas, K. M.; Cai, H. Y.; Dugwell, D. R.;

Kandiyoti, R. Energy Fuels 1996, 10 (2), 409.

(63) Nicholls, P. M.; Nelson, P. Energy Fuels 2000, 14 (4), 943.

(64) Chan, L. K.; Sarofim, A. F.; Beér, J. M. Combust. Flame 1983 52,37 .

65) Suuberg, E. M.; Teng, H.; Calo, J. M. 23th Symposium (International) on Combustion; The Combustion Institute, 1990; p 1199.

(66) Teng, H.; Suuberg, E. M.; Calo, J. M. Energy Fuels 1992, 6 (4), 398

(67) Matos, M. A. A. Ph.D. Thesis, Departamento de Ambiente e Ordenamento, Universidade de Aveiro, Portugal, 1995.

(68) Aarna, I.; Suuberg, E. M. Fuel 1997, 76 (6), 475. 


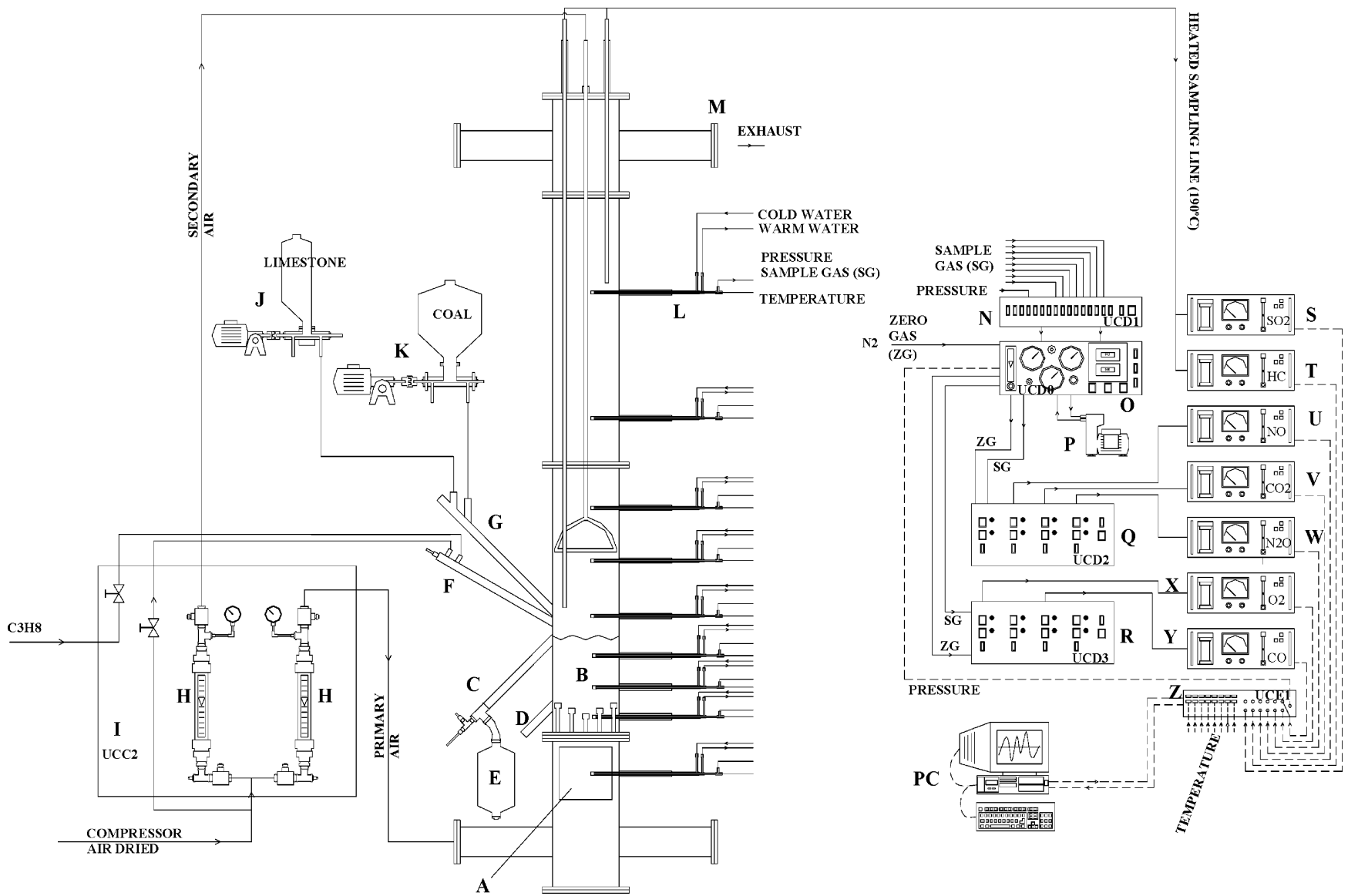

Figure 1. Schematic illustration of the experimental pilot ABFBC setup: dashed line, electric circuit; continuous line, pneumatic circuit; A, primary air heating system; B, sand bed; C, bed solids level control; D, bed solids discharge; E, bed solids discharge silo; F, propane burner system, G, coal and limestone addition port; H, air flow meter; I, control and command unit; J, limestone feeder; K, coal feeder; L, gas sampling probe; M, exhaust duct; N, O, Q, R, command and gas distribution units; P, gas sampling pump; S, T, U, V, W, X, Y, automatic on-line gas analyzers $\left(\mathrm{SO}_{2}, \mathrm{HC}, \mathrm{NO}, \mathrm{CO}_{2}, \mathrm{~N}_{2} \mathrm{O}, \mathrm{O}_{2}, \mathrm{CO}\right)$; Z, electronic command unit; PC, computer data acquisition and control system.

such as $\mathrm{CO}$ and $\mathrm{O}_{2}$ appear to favor the $\mathrm{NO}$ reduction by char. ${ }^{4,26,68,69,74,78,80-83}$

Reactions that are responsible for the heterogeneous catalytic formation and destruction of $\mathrm{NO}$ can occur at solid surfaces such as sand, calcinated limestone, char,

(69) Chambrion, P.; Orikasa, H.; Suzuki, T.; Kyotani, T.; Tomita, A. Fuel 1997, 76 (6), 493

(70) Chambrion, P.; Suzuki, T.; Zhang, Z.-G.; Kyotani, T.; Tomita, A. Energy Fuels 1997, 11 (3), 681.

(71) Chambrion, P.; Kyotani, T.; Tomita, A. Energy Fuels 1998, 12 (2), 416 .

(72) Chambrion, P.; Kyotani, T.; Tomita, A. 27th Symposium (International) on Combustion; The Combustion Institute, 1998; p 3053.

(73) Calo, J. M.; Suuberg, E. M.; Aarna, I.; Linares-Solano, A.; Salinas-Martínez de Lecea, C.; Illán-Goméz, M. J. Energy Fuels 1999 13 (3), 761.

(74) Molina, A.; Eddings, E. G.; Pershing, D. W.; Sarofim, A. F. Prog. Energy Combust. Sci. 2000, 26, 507.

(75) Wongtanakitcharoen, S.; Tatiyakiatisakun, T.; Rirksomboon, T.; Long, Q. Q.; Osuwan, S.; Malakul, P.; Yang, R. T. Energy Fuels 2001, 15, 1341 .

(76) Arenillas, A.; Rubiera, F.; Pis, J. J. Environ. Sci. Technol. 2002, 36 (24), 5498

(77) Zhao, Z.; Li, W.; Qiu, J.; Li, B. Fuel 2002, 81, 2343.

(78) Zhao, Z.; Qiu, J.; Li, W.; Chen, H.; Li, B. Fuel 2003, 82, 949.

(79) Glarborg, P.; Jensen, A. D.; Johnsson, J. E. Prog. Energy Combust. Sci. 2003, $29,89$.

(80) Tullin, C. J.; Sarofim, A. F.; Beer, J. M. 12th International Conference on FBC; ASME, 1993; p 599

(81) Rodriguez-Mirasol, J.; Ooms, A. C.; Pels, J. R.; Kapteijn, F.; Moulijn, J. A. Combust. Flame 1994, 99, 499.

(82) Li, Y. H.; Lu, G. Q.; Rudolph, V. Chem. Eng. Sci. 1998, 53 (1),

(83) Hayashi, J.-I.; Hirama, T.; Okawa, R.; Taniguchi, M.; Hosoda, H.; Morishita, K.; Li, C.-Z.; Chiba, T. Fuel 2002, 81, 1179 and coal ash. 16,18,26,84-88 Catalytic oxidation of HCN and $\mathrm{NH}_{3}$ mainly yields NO. 16,18,26,88 Catalytic destruction of $\mathrm{NO}$ can occur via reduction by $\mathrm{CO}$ and $\mathrm{H}_{2}$ and also by its own precursors $\mathrm{HCN}$ and $\mathrm{NH}_{3}$ over char, calcinated limestone, $\mathrm{CaS}$, sand, and coal ash. The $\mathrm{NO}$ reduction by $\mathrm{CO}$, catalyzed by char, is very important. $18,26,68,78,82,89-92$ The coal ash composition determines the catalytic activity in this reaction, ${ }^{91}$ and the bed sand (quartz) seems to be a poor catalyst for this reaction. ${ }^{67,91}$

\section{Pilot-Plant Description}

The rig is composed of a pilot-scale fluidized bed reactor and ancillaries and a sampling and data acquisition system (Figure

(84) Hansen, P. F. B.; Dam-Johansen, K.; Johnsson, J. E.; Hulgaard, T. Chem. Eng. Sci. 1992, 47 (9-11), 2419.

(85) Hansen, P. F. B.; Dam-Johansen, K. 12th International Conference on FBC; ASME, 1993; p 779.

(86) Olanders, B.; Stromberg, D. Energy Fuels 1995, 9 (4), 680.

(87) Johnsson, J. E.; Jensen, A. 38th IEA Fluidized Bed Conversion Meeting, Workshop on NO/ $\mathrm{N}_{2} \mathrm{O}$ Formation and Destruction in Fluidized Bed Combustors, 1999; p 24.

(88) Svoboda, K.; Cermák, J.; Trnka, O. Chem. Papers 2000, 54 (2), 104.

(89) Johnsson, J. E.; Dam-Johansen, K. 11th International Conference on FBC; ASME, 1991; p 1389.

(90) Goel, S. K.; Morihara, A.; Tullin, C. J.; Sarofim, A. F. 25th Symposium (International) on Combustion; The Combustion Institute 1994; p 1051.

(91) Johnsson, J. E.; Jensen, A.; Nielsen, J. S. 15th International Conference on FBC; ASME, 1999; p 859.

(92) Aarna, I.; Suuberg, E. M. Energy Fuels 1999, 13 (6), 1145. 
Table 1. Experimental Conditions

\begin{tabular}{ccccc}
\hline & \multicolumn{2}{c}{ total air } & & \\
\cline { 2 - 3 } bed temp $\left({ }^{\circ} \mathrm{C}\right)$ & $\begin{array}{c}\text { primary } \\
\text { air }(\%)\end{array}$ & $\begin{array}{c}\text { secondary } \\
\text { air }(\%)\end{array}$ & $\begin{array}{c}\text { first stage } \\
\text { stoichiometry }^{a}\end{array}$ & $\begin{array}{c}\text { excess } \\
\text { air }^{b}(\%)\end{array}$ \\
\hline $750,825,900$ & 100 & 0 & 1.10 & 10 \\
& & & 1.25 & 25 \\
$750,825,900$ & \multirow{2}{*}{80} & \multirow{2}{*}{20} & 1.50 & 50 \\
& & & 0.88 & 10 \\
$750,825,900$ & \multirow{2}{*}{60} & \multirow{2}{*}{40} & 1.00 & 25 \\
& & & 0.66 & 50 \\
& & & 0.75 & 10 \\
& & 0.90 & 50
\end{tabular}

${ }^{a}$ Primary air flow rate/stoichiometric air flow rate. ${ }^{b}[$ (Total air flow rate/stoichiometric air flow rate) -1$] \times 100$.

Table 2. Chemical Composition of Coal

\begin{tabular}{|c|c|c|}
\hline & bituminous coal & anthracite coal \\
\hline \multicolumn{3}{|c|}{ Proximate Analysis (wt \%) } \\
\hline moisture & 4.4 & 3.16 \\
\hline ash & 13.8 & 6.79 \\
\hline volatile matter & 28.5 & 2.04 \\
\hline fixed $\mathrm{C}$ & 53.3 & 88.01 \\
\hline \multicolumn{3}{|c|}{ Ultimate Analysis (wt \%) (as given) } \\
\hline ash & 13.8 & 6.79 \\
\hline $\mathrm{C}$ & 65.97 & 85.73 \\
\hline $\mathrm{H}$ & 4.27 & 1.36 \\
\hline $\mathrm{N}$ & 1.67 & 0.62 \\
\hline $\mathrm{S}$ & 0.88 & 1.23 \\
\hline $\mathrm{O}$ (by difference) & 13.41 & 4.27 \\
\hline
\end{tabular}

1). The control of the reactive, gas sampling, and data acquisition (temperature, pressure and gas concentrations) systems is made in real time by a computer-based control and data acquisition hardware/software system. A detailed description of the experimental setup can be found elsewhere. ${ }^{67,93}$

The reactor is a thermally insulated AISI 310 SS tube 0.25 $\mathrm{m}$ i.d. and $3 \mathrm{~m}$ height, with a $0.35 \mathrm{~m}$ static bed height. Coal was fed at the top of the bed (at $0.35 \mathrm{~m}$ from the air distributor plate). Secondary air was injected $0.30 \mathrm{~m}$ above the bed surface.

The operating conditions used are summarized in Table 1. The primary air flow-rate was adjusted to keep the fluidizing velocity at about 3 times the minimum, between 0.28 and 0.32 $\mathrm{m} \mathrm{s}^{-1}$, depending on the bed temperature. On following, the excess air and the degree of air staging were established independently by proper adjustment of the coal and secondary air flow rates.

Two types of coals were used: a South African bituminous coal and a Portuguese anthracite. Both were sieved to 500$4000 \mu \mathrm{m}$ size, and their properties are shown in Table 2.

Gas samples were withdrawn from inside the bed and the freeboard through water-cooled probes and passed through a series of paramagnetic $\left(\mathrm{O}_{2}\right)$, nondispersive IR $\left(\mathrm{CO}_{2}, \mathrm{CO}, \mathrm{N}_{2} \mathrm{O}\right.$, $\mathrm{SO}_{2}$ ), chemiluminescence (NO), and flame ionization (hydrocarbons) analyzers. Due to the existence of radial concentration gradients, the probes tips were positioned at the distance of $0.07 \mathrm{~m}$ from the inner wall.

The following definitions are used:

stoichiometry $=($ total air flow rate $) /($ stoichiometric air flow rate);

excess air $(\%)=($ stoichiometry -1$) \times 100$; and

first stage stoichiometry $=($ primary air flow rate $) /($ stoichiometric air flow rate).

\section{Experimental Results and Discussion}

4.1. Axial Concentration Profiles. The NO axial concentration profiles are shown in Figures 2 and 3 for

(93) Tarelho, L. A. C. Ph.D. Thesis, Departamento de Ambiente e Ordenamento, Universidade de Aveiro, Portugal, 2001. both types of coal. The most remarkable feature about them is that the NO concentration is high inside the bed and decreases progressively along the freeboard toward the exit flue gas. However, during bituminous coal combustion with high air staging and low to moderate excess air, and also for anthracite coal with high air staging and low excess air, the NO concentration peaks at halfway the bed height, reaches a minimum just above the bed surface, and peaks again near the secondary air injection point.

Two notes of advertence should be made about those figures:

(i) Because of a possible correlation between the concentration and velocity in the bubble phase and in the particle phase, the measured concentrations inside the bed may be biased. ${ }^{94,95}$ In fact, radial concentration gradients inside the bed were observed during the experiments. ${ }^{93,96}$ Consequently, the gas samples inside the bed were collected at halfway between the wall and the axial axis of the reactor (section 3), as an attempt to sample both phases. Therefore, one would expect that they give a representation of the time average concentration in that position, but caution must be taken, because they could give a poor representation of the concentration of the gas flow inside the bed.

(ii) Because gas concentrations (in ppm) do not account for the dilution by the secondary air, the concentrations (in ppm) below it are not entirely comparable with those measured downstream of the secondary air injection. However, when plotting the information of Figures 2 and 3 using the units of $\mathrm{mg}$ of $\mathrm{N}-\mathrm{NO} / \mathrm{g}$ of coal-N (see examples in Figure 4), the trends are the same. The new unit is obviously not affected by secondary air dilution and is still a measure of local NO availability; caution must be taken when analyzing the values inside the bed, since the gas concentration measured there could give a poor representation of the concentration of the gas flow, as referred above.

The observed behavior is an indication that the NO formation starts at the fluidizing air inlet, where there is oxygen available. Comparison with the corresponding $\mathrm{CO}$ axial concentration profiles (Figure 5) shows that the $\mathrm{CO}$ and NO profiles follow a similar trend, namely, that both attained high concentrations inside the bed, which is consistent with the idea that it is in the bed that the coal/char particles are oxidized to yield NO. On the other hand, the decrease of the NO concentration along the freeboard is probably due to the predominance of destruction reactions by species released at the bed surface, or upcoming from the bed. Also the dilution caused by secondary air injection influences the NO concentration, but a decrease in coal-N conversion to NO with freeboard height is indeed observed (Figure 4). The same general behavior along the reactor has been reported before, both in bubbling ${ }^{1,6,94}$ and circulating fluidized beds; $8,16,20,97$ however, under their experi-

(94) Walsh, P. M.; Chaung, T. Z.; Dutta, A.; Beér, J. M.; Sarofim, A. F. 19th Symposium (International) on Combustion; The Combustion Institute, $1982 ;$ p 1281

(95) Lyngfelt, A.; Amand, L.-E.; Leckner, B. 26th Symposium (International) on Combustion; The Combustion Institute, 1996; p 3253.

(96) Tarelho, L. A. C.; Matos, M. A. A.; Pereira, F. J. M. A. Axial and radial $\mathrm{CO}$ concentration profiles in an atmospheric bubbling $\mathrm{FB}$ combustor. Submitted to Fuel. 

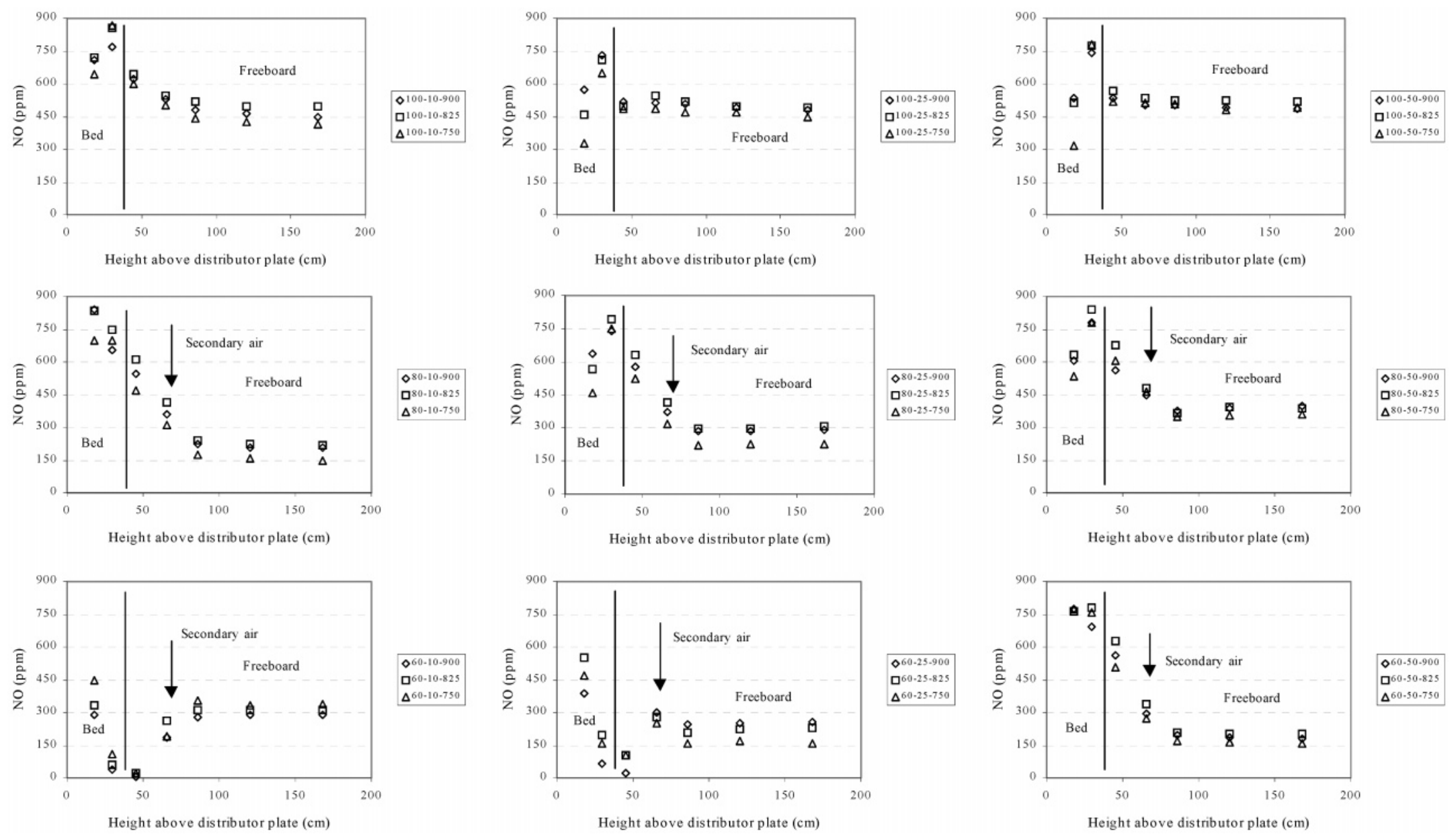

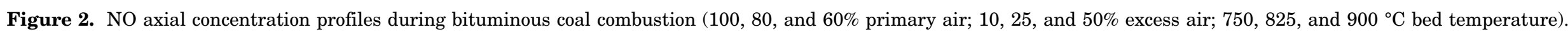




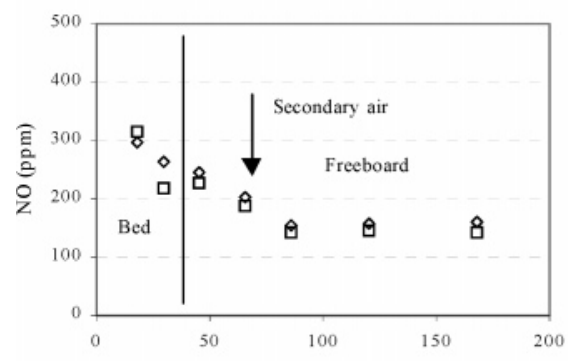

Height above distributor plate $(\mathrm{cm})$

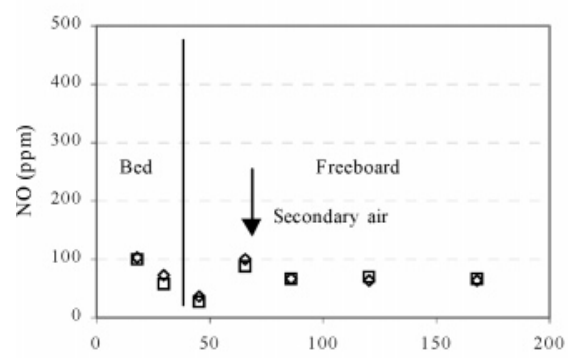

Height above distributor plate ( $\mathrm{cm}$ )
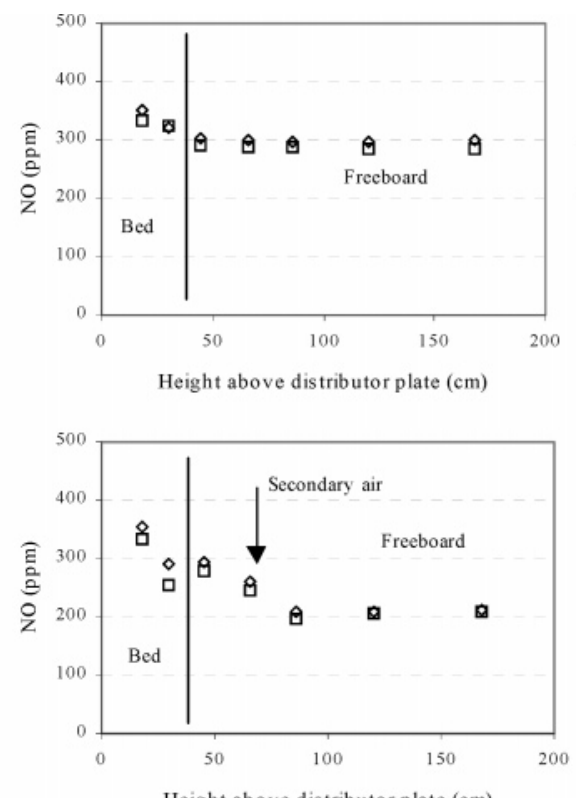

$$
\begin{aligned}
& 0^{80-10-900} \\
& \square^{80-10-825}
\end{aligned}
$$

Height above distributor plate (cm)

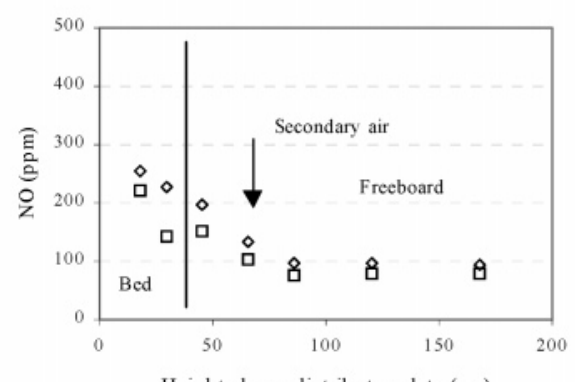

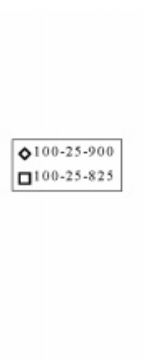
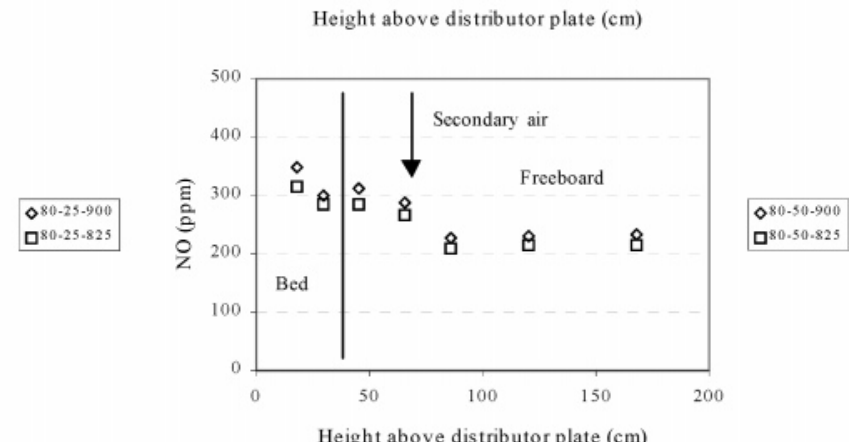

\begin{tabular}{|l|}
\hline$\Delta^{80-50-900}$ \\
$\square^{80-50-825}$
\end{tabular}
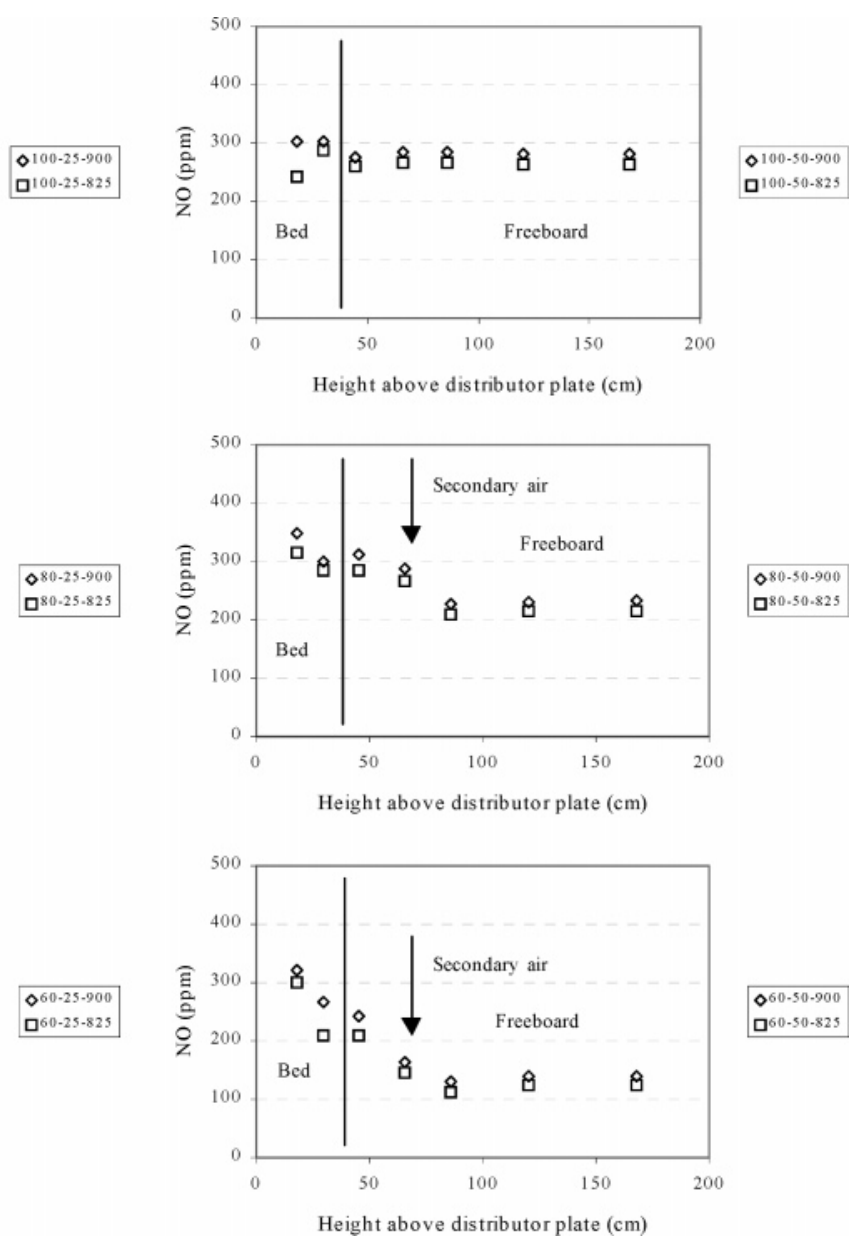

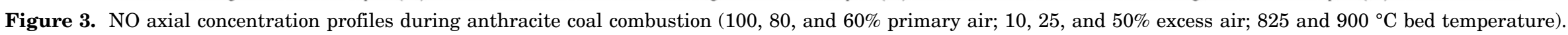



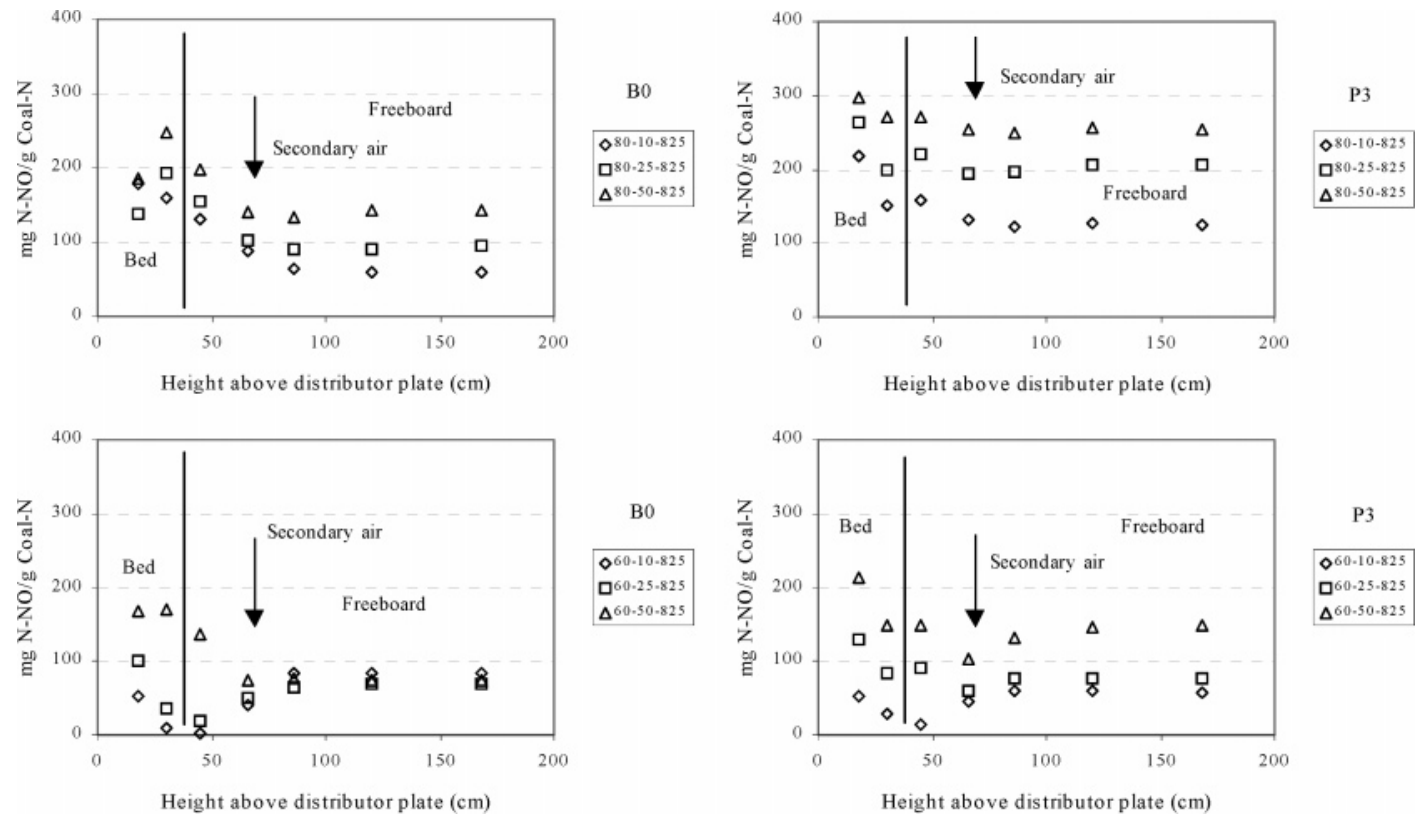

Figure 4. NO axial profiles, in terms of coal-N conversion to NO, during bituminous (B0) and anthracite (P3) coal combustion ( 80 and $60 \%$ primary air; 10,25 , and $50 \%$ excess air; $825^{\circ} \mathrm{C}$ bed temperature).
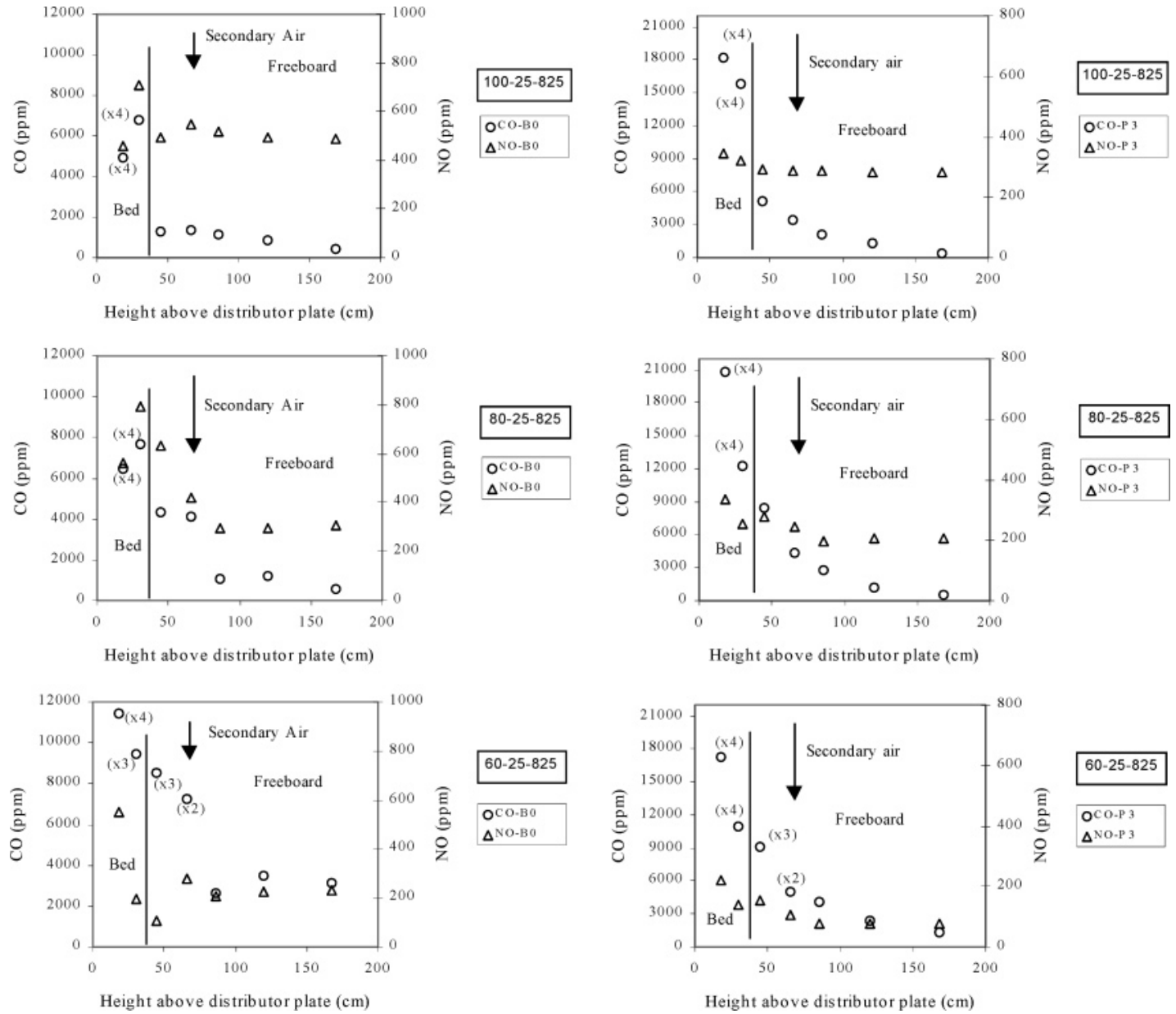

Figure 5. NO and CO axial concentration profiles during bituminous (B0) and anthracite (P3) coal combustion (100, 80, and $60 \%$ primary air; $25 \%$ excess air; $825{ }^{\circ} \mathrm{C}$ bed temperature).

mental conditions the coal feed point was located at the bottom of the bed and not at the bed surface, as in our work. The relevance of the coal feed point location in the context of $\mathrm{NO}$ formation is related to the volatiles evolution. The volatile species contribution to the NO formation and destruction could be important when the coal has significant volatile matter content, like, for

(97) Zhao, J.; Brereton, C. M. H.; Grace, J. R.; Lim, C. J.; Legros, R Fuel 1997, 76 (9), 853. 

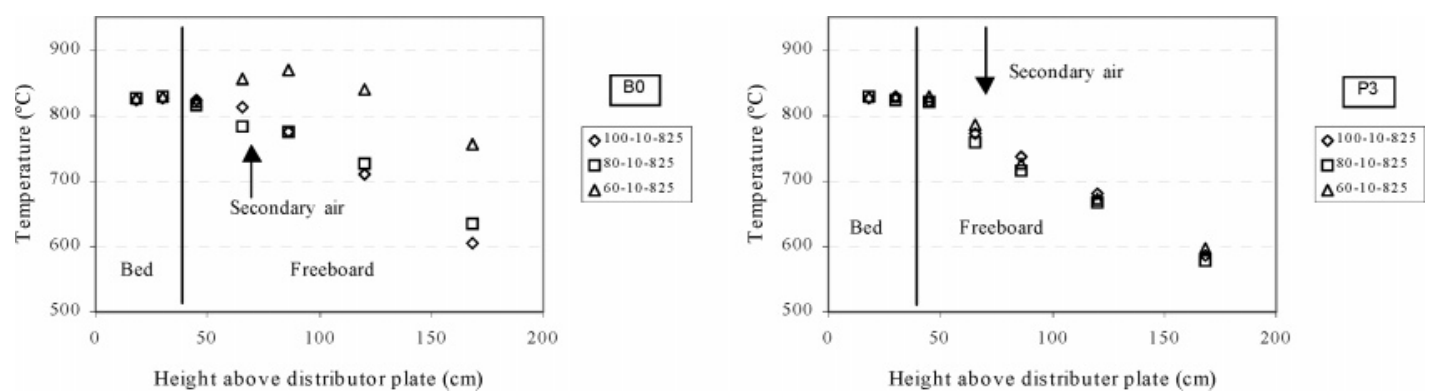

Figure 6. Axial temperature profile along the reactor during bituminous (B0) and anthracite (P3) coal combustion (100, 80, and $60 \%$ primary air; $10 \%$ excess air; $825^{\circ} \mathrm{C}$ bed temperature).
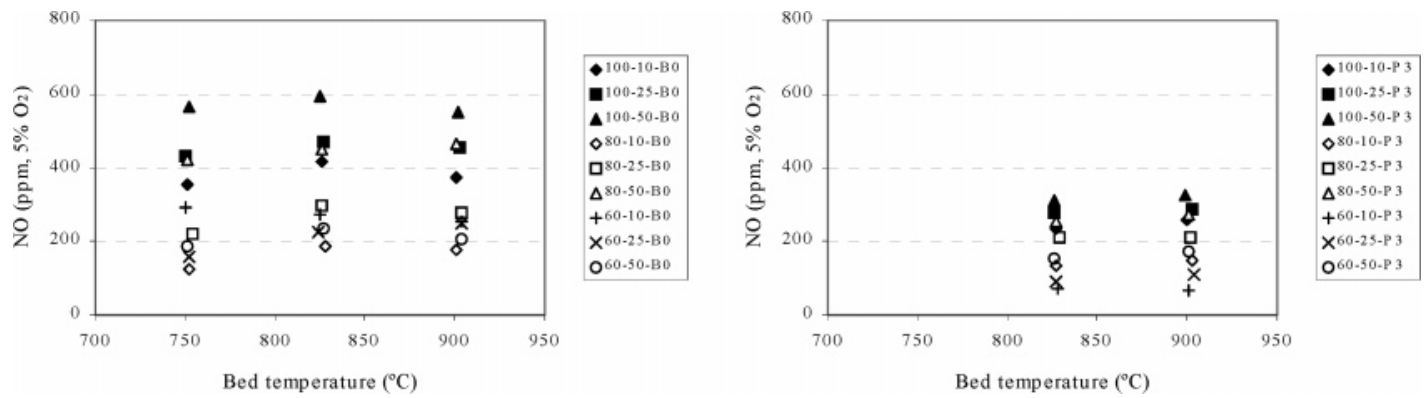

Figure 7. Effect of bed temperature on the NO flue gas (corrected for $5 \% \mathrm{O}_{2}$ ), during bituminous (B0) and anthracite (P3) coal combustion (100, 80, and $60 \%$ primary air; 10,25 , and $50 \%$ excess air; 750,825 , and $900{ }^{\circ} \mathrm{C}$ bed temperature).

example, the bituminous coal used here. In fact, in the present work it appeared that a significant fraction of the volatiles was released near the coal feed point (that is, at bed surface), as shown by our visual observations of the behavior of the bed surface and coal particles as they entered the reactor. Since in a bubbling bed the freeboard is a solids-lean region, the observed behavior is suggestive of a significant contribution from the homogeneous NO chemistry. On the basis of the $\mathrm{CO}$ and hydrocarbons behavior in the reactor, ${ }^{93,96}$ we can infer that in the freeboard there is a significant concentration of reducing species capable of homogeneous NO destruction, thus explaining the observed NO concentration decrease with height. For example, the NO destruction by reaction with $\mathrm{NCO}$ along the freeboard is coherent with the $\mathrm{N}_{2} \mathrm{O}$ behavior observed in this same study, the latter showing an increase with height along the freeboard. ${ }^{98}$

The significant NO formation near the secondary air injection point, during high air staging with low to moderate excess air, is also associated with the oxidation of combustible species, mainly gases, coming from the substoichiometric first stage. This secondary combustion is coherent with the temperature profiles observed (Figure 6), especially during bituminous coal combustion, where comparatively higher freeboard temperatures were observed as a result of the transference of a significant part of volatiles burning to this region. This shows that under those operating conditions the NO flue gas concentration is strongly determined by the secondary combustion zone (Figures 2-4). Besides being visible for both coals, this effect is much more pronounced in the case of bituminous coal combustion and must be related with the rank of the coal. In fact, although a similar NO concentration profile is observed

(98) Tarelho, L. A. C.; Matos, M. A. A.; Pereira, F. J. M. A. Axial concentration profiles and $\mathrm{N}_{2} \mathrm{O}$ flue gas in a pilot scale bubbling fluidised bed coal combustor. Submitted to Fuel Process. Technol. along the freeboard for both coals, the gradients are less evident in the case of anthracite (Figures 2 and 3). These results show the importance of the volatiles of lower rank coals in the homogeneous NO chemistry, since the volatile matter content of anthracite is comparatively smaller.

Another interesting point is the observation that, besides the NO formation inside the bed, the NO can also be almost destroyed there, depending on the stoichiometric conditions, as can be observed during high air staging with low to moderate excess air (Figures 2-4). This shows the relevance of the heterogeneous environment prevailing inside the bed on the NO chemistry, as discussed in section 2.

4.2. Effect of Bed Temperature. During anthracite combustion we can observe a positive correlation between the bed temperature $\left(825-900{ }^{\circ} \mathrm{C}\right)$ and the NO flue gas (Figure 7). In the case of bituminous coal, a similar behavior is observed in the range $750-825^{\circ} \mathrm{C}$, but in the higher temperature range $\left(825-900{ }^{\circ} \mathrm{C}\right)$ the effect is not clear, since a positive or a negative correlation can be observed (Figure 7). For this coal, the situation with high excess fuel in the bed (60\% primary air with $10 \%$ excess air) is an exception, since a negative correlation is observed between NO flue gas and bed temperature in the range $750-900{ }^{\circ} \mathrm{C}$. However, as we saw earlier, under this condition the NO flue gas is essentially determined by the secondary combustion zone (Figure 2). When comparing Figures 7 and 8, we can see that this is actually the only situation where (i) the bed and freeboard temperatures are inversely correlated, and therefore, (ii) we could say that, even in this particular situation, we can speak of a positive correlation between NO flue gas and (freeboard) temperature. Perhaps this could be one of the reasons for the different findings reported in the literature, concerning the effect of bed temperature on NO flue gas. 

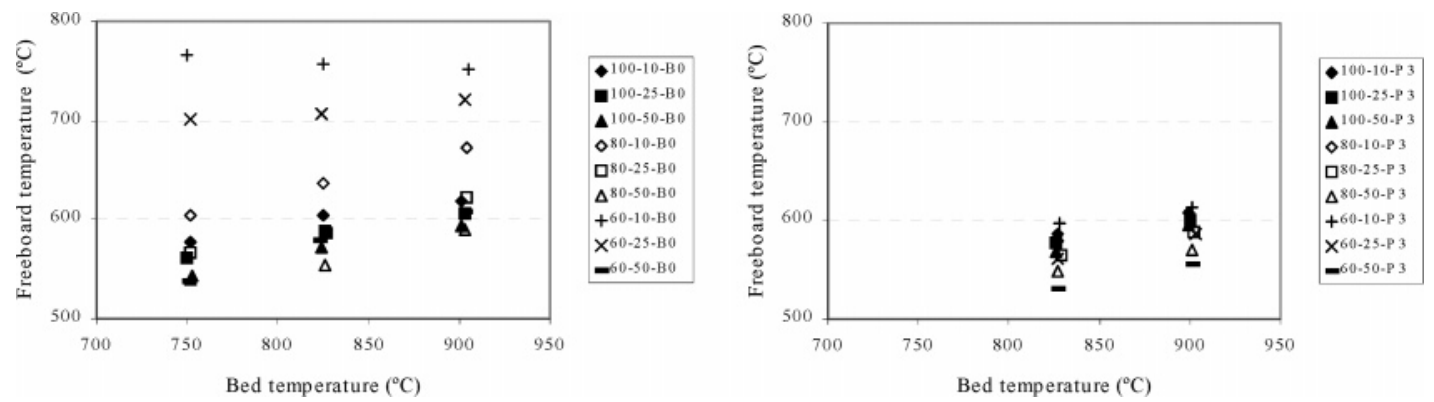

Figure 8. Effect of bed temperature on the freeboard temperature (measured $1.7 \mathrm{~m}$ above distributor plate) during bituminous (B0) and anthracite (P3) coal combustion (100, 80, and 60\% primary air; 10, 25, and $50 \%$ excess air; 750,825 , and $900{ }^{\circ} \mathrm{C}$ bed temperature).
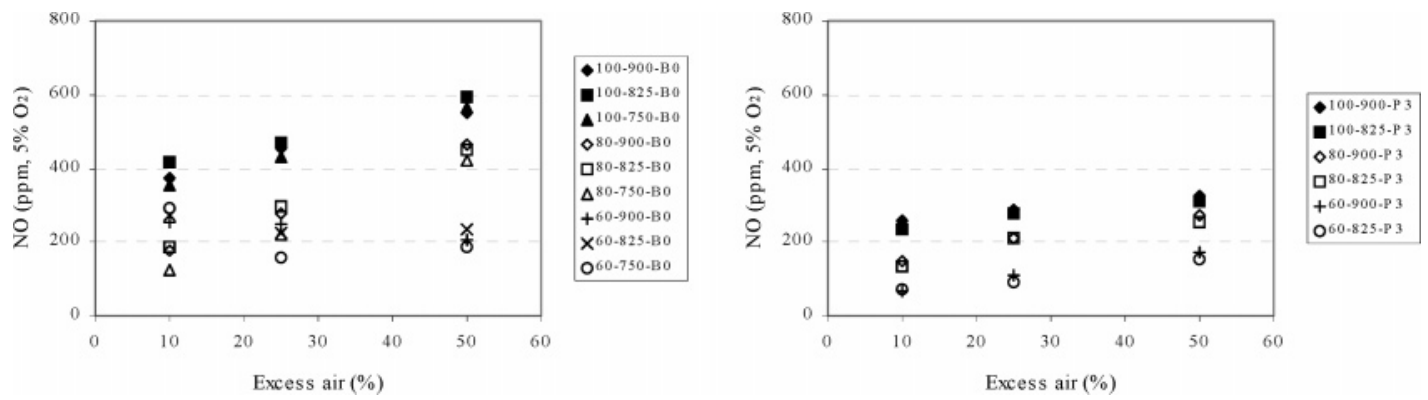

Figure 9. Effect of excess air on the NO flue gas (corrected for $5 \% \mathrm{O}_{2}$ ), during bituminous (B0) and anthracite (P3) coal combustion $\left(100,80\right.$, and $60 \%$ primary air; 10,25 , and $50 \%$ excess air; 750,825 , and $900{ }^{\circ} \mathrm{C}$ bed temperature).
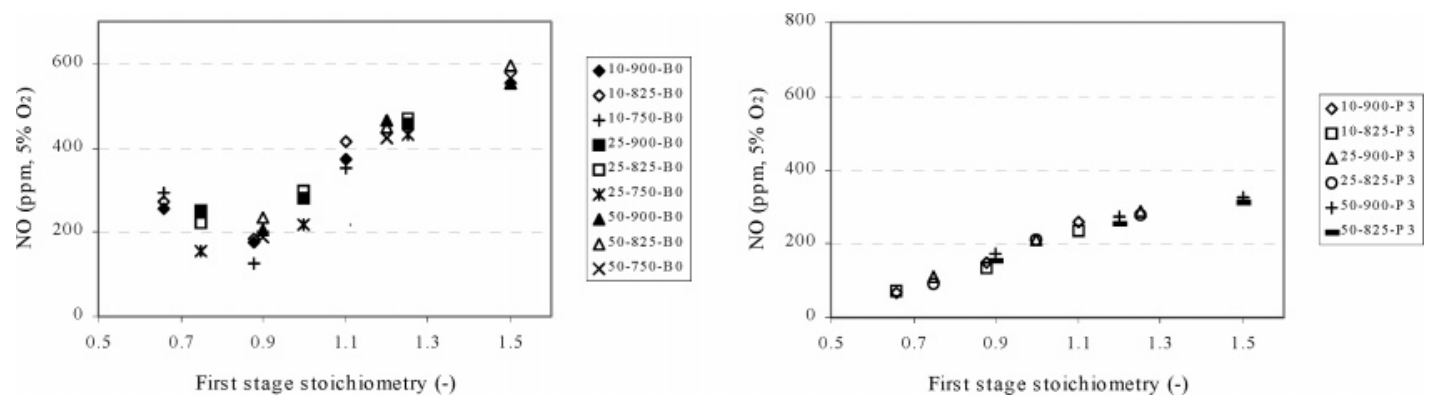

Figure 10. Effect of first stage stoichiometry on the NO flue gas (corrected for $5 \% \mathrm{O}_{2}$ ), during bituminous (B0) and anthracite (P3) coal combustion (100, 80, and $60 \%$ primary air; 10, 25, and 50\% excess air; 750 , 825, and $900{ }^{\circ} \mathrm{C}$ bed temperature).

The bed temperature is closely related with the concentrations of char and reducing gaseous species in the reactor. In this respect, a combination of the two following effects is observed in the present work: (i) with a decrease in the bed temperature, the concentration of those species increases, thus favoring the NO destruction by heterogeneous reaction with char and catalytic reactions over the bed particles (therefore, one should expect lower NO concentrations at the lower temperatures) and (ii) the NO destruction reactions, in particular over char, increase with increasing temperature. ${ }^{26,67,82}$ In this way, the increase in the NO flue gas with the bed temperature increase in the range 750$825{ }^{\circ} \mathrm{C}$ shows the first effect, whereas the decrease in the NO flue gas with an increase in bed temperature (observed in some conditions from 825 to $900{ }^{\circ} \mathrm{C}$ ) shows the temperature influence on the NO destruction reactions, in comparison to the ones leading to its formation.

The decrease in NO flue gas with the temperature increase from 750 to $900{ }^{\circ} \mathrm{C}$ observed during high air staging with low excess air should be regarded as a special case, as discussed earlier. Under those circumstances the temperature influence could be related with the amount of reduced species that enters the second stage. That amount increases with decreasing bed temperature, and consequently, its oxidation gives rise to relatively high NO formation, which is not destroyed in the upper part of the freeboard.

4.3. Effect of Stoichiometry (Excess Air and Air Staging). Basically, the effects of increasing excess air and decreasing air staging are concurrent, in the sense that they both result in higher localized oxygen availability at the first stage level. When the NO flue gas concentrations are normalized to $5 \% \mathrm{O}_{2}$ in the flue gases, a positive correlation between $\mathrm{NO}$ flue gas and excess air is observed (Figure 9). The operation with high air staging during bituminous coal combustion is an exception, since a minimum in the $\mathrm{NO}$ flue gas is attained for $25 \%$ excess air at 750 and $825^{\circ} \mathrm{C}$, and a negative correlation is observed at $900{ }^{\circ} \mathrm{C}$.

On the other hand, a negative correlation between the NO flue gas and the degree of air staging is observed (Figure 10; the increase in air staging is equivalent to a decrease in the first stage stoichiometry). Again, the bituminous coal combustion with low excess air constitutes an exception, since a moderate air staging is more favorable in order to get a lower NO flue gas concentration. For this coal a minimum in the NO flue gas is 

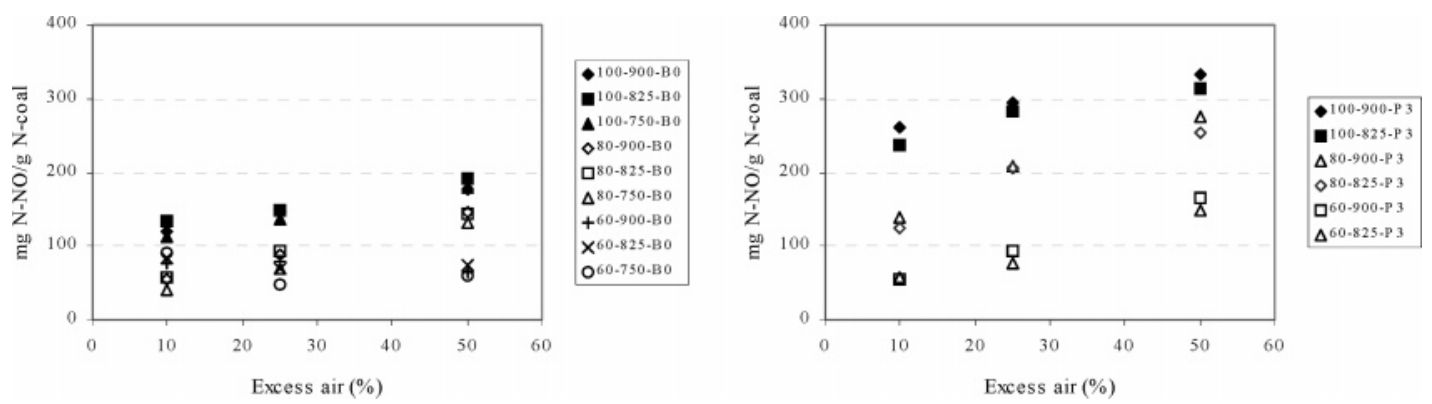

Figure 11. NO flue gas, in terms of coal-N conversion to NO, during bituminous (B0) and anthracite (P3) coal combustion (100, 80 , and $60 \%$ primary air; 10,25 , and $50 \%$ excess air; 750,825 , and $900{ }^{\circ} \mathrm{C}$ bed temperature).

observed at a first stage stoichiometry around 0.9 (Figure 10). Otherwise, for anthracite coal the NO flue gas always decreases upon decreasing the first stage stoichiometry (increasing the air staging).

Insofar as the influence of oxygen availability is concerned, these results for excess air and air staging are coherent and mutually confirmative. The tendency for an increase in the NO flue gas with an increase in stoichiometry results from a higher oxygen availability in the reactor, both in the bed and in the freeboard. The following phenomena could result from the increase in the oxygen concentration, which would, then, explain the observed results: (i) a higher fuel-N oxidation to $\mathrm{NO}$ and (ii) a lower concentration of NO reducing species (such as char, $\mathrm{CO}, \mathrm{H}_{2}$, hydrocarbons, $\mathrm{HCN}, \mathrm{NH}_{3}$ ).

Bearing in mind the assumption that NO originates from fuel-N, the relevance of oxygen availability regarding the oxidation of char- $\mathrm{N}$ and volatile nitrogencontaining species $\left(\mathrm{NH}_{3}, \mathrm{HCN}\right.$, and tars) is self-evident. In fact, the conversion of volatile nitrogen-containing species to NO is very much dependent on the oxygen concentration near the devolatilization region, and this dependence is often used to reduce the fuel-N conversion to $\mathrm{NO} ;{ }^{27}$ the operation with air staging is an example.

On the other hand, the oxygen presence is noticeable by means of an indirect effect, that is, its influence on the concentration of char and gaseous reducing species (like $\mathrm{CO}, \mathrm{H}_{2}, \mathrm{HCN}, \mathrm{NH}_{3}$, and several hydrocarbons) with potential for NO destruction. With an increase in the oxygen concentration there is a decay in the concentration of those reducing species. ${ }^{5,16,17}$ In fact, during our experiments a decrease in both $\mathrm{CO}$ and hydrocarbons concentrations was observed as a result of an increase in the stoichiometry. ${ }^{93,96}$

4.4. Effect of Coal Rank. The normalized NO concentrations in Figure 9 are expressed in terms of conversion of fuel-N to NO in Figure 11. The comparison of these figures shows that, in the case of anthracite, when compared with bituminous coal: (i) the conversion is higher, despite its lower fuel-N and volatile matter content and (ii) the flue gas concentrations are lower, which is coherent with its lower fuel-N and volatile matter content. Therefore, although having a higher conversion of fuel-N to NO, the NO flue gas for anthra- cite is lower. While the first aspect emphasizes the coal reactivity toward $\mathrm{NO}$, the second shows that a lower nitrogen content coal can yield a lower NO flue gas.

\section{Conclusions}

The experimental results confirm that the NO formation starts inside the bed. On the other hand, they also show that the heterogeneous reactive environment inside the bed can efficiently destroy the NO formed.

During the combustion of bituminous coal and anthracite, the NO flue gas concentrations (normalized to $5 \% \mathrm{O}_{2}$ in the flue gases) were in the range 130-600 and 60-330 ppm, respectively. The highest values occurred during single stage operation with high excess air $(50 \%)$ at moderate bed temperature $\left(825^{\circ} \mathrm{C}\right.$ ) (for bituminous coal) or high bed temperature $\left(900^{\circ} \mathrm{C}\right.$ ) (for anthracite), whereas the lowest values occurred during moderate air staging (20\% secondary air) with low excess air $(10 \%)$ at low bed temperature $\left(750{ }^{\circ} \mathrm{C}\right.$ ) (for bituminous coal) or high air staging (40\% secondary air) with low excess air $(10 \%)$ at moderate/high bed temperature (for anthracite).

Overall, the results show that the bed temperature increase does not affect the NO flue gas concentration significantly, whereas increasing the excess air increases the NO flue gas. The air staging operation is very effective in lowering the NO flue gas, but there is a limit for the first stage stoichiometry below which the NO flue gas starts rising again in result of the secondary combustion. This effect could be related with the coal rank.

Most of the observed results could be qualitatively interpreted in terms of a set of homogeneous and heterogeneous reactions, where catalytic surfaces (such as char, sand, and coal ash) play an important role in the formation and destruction of NO.

Acknowledgment. The authors wish to thank the "Fundação para a Ciência e Tecnologia" for the financial support in the project PRAXIS/3/3.1/ENR/94. One of us (L.A.C.T.) wishes to thank the "Fundação para a Ciência e Tecnologia" for a Ph.D. grant.

EF049940L 